\title{
WHEN SCIENCE BECOMES INTERACTIVE: A COLLABORATIVE PROJECT IN A TEACHING-LEARNING NETWORK
}

\author{
Inês Amaral ${ }^{1}, M^{a}$ Isabel Rodríguez Fidalgo ${ }^{2}, M^{a}$ Luz Fidalgo Mayo ${ }^{3}$, Javier \\ Ignacio Beitia Gómez de Segura ${ }^{3}$ \\ ${ }^{1}$ Centro de Estudos de Comunicação e Sociedade da Universidade do Minho / Universidade \\ Autónoma de Lisboa / Instituto Superior Miguel Torga (PORTUGAL) \\ ${ }^{2}$ Universidad de Salamanca(SPAIN) \\ ${ }^{3}$ Universidad del Pais Vasco (SPAIN)
}

\begin{abstract}
This paper presents the results of an international Project of Teaching Innovation developed between three universities (University of the Basque Country; University of Salamanca and Autonomous University of Lisbon). The focus was the process of virtualization of teaching contents. The main objective of this project was to plan and create digital didactic materials in an interactive format within an interdisciplinary perspective. Teachers and students from Science and Communication Sciences conceptualized and developed digital content of a specific course (Inorganic Chemistry) to promote an active learning framework in a digital environment.

The starting point for this project was the new educational model of higher education and the use of technology as an element to empower the teaching-learning process. This paper provides an articulated analysis around this project, which focuses its main interest on the great importance that, the practical work that the students performs within the subjects has acquired in the new curricula, both at the level of hours of work and of specific weight in the final grade.
\end{abstract}

Keywords: interactive science; teaching-learning networks; new educational models.

\section{INTRODUCTION}

In the last decade the implementation of the new educational model of higher education (EMHE) has brought with it a commitment to active didactic methodologies, centred on the student who now must acquire knowledge and skills in an autonomous and active learning framework, always having as reference the professional context current. A key element in order to materialize the aforementioned aspects is the use of the new Information and Communication Technologies (ICT), mainly those related to Internet technology, within the educational context both with regard to the mentioned processes of teaching-learning (eLearning) and its result (virtualization of teaching contents) [1].

A key player in that methodological renovation has been the unstoppable advance that have developed ICT, mainly related to Internet technology, since the importance and impact that new technologies have caused in society [1]. Internet has become the basis of information for society and is creating new communication and information structures that are changing the rules of the game. New technologies promote a change in the systems of obtaining, forming, conserving and transmitting information.

\subsection{New Model of Higher Education}

The two key areas of the theoretical foundation of this paper are the so-called EMHE building anchors and the concept of "educational innovation or teaching", both intrinsically connected. There are many changes and changes that have taken place in the context of higher education since the process of convergence of higher education within the European space was initiated following the statements of the Sorbonne (1998) and Bologna (1999). In this context, the construction of a Europe of knowledge as a decisive factor for social growth and is raised to increase the competitiveness of the European higher education system. In this respect it should be specified that the Bologna process has generated three types of transformations: structural, curricular and organizational. Structures have primarily affected the division and duration of the educational stages, the curricular to the definition, the design and the development of the curriculum and the organizational ones to the conditions in which the teaching/learning process is developed [2]. 
According to Caldevilla [3], transformations affecting the teaching/learning process are those that emphasize these main three issues: the change of the educational weight of the teacher to the student, the incorporation of private enterprise into the process of student training, and the universal use of new information and communication technologies to the daily development of classes.

Based on these approaches emerges the imperative need to carry out within the different curricula a renewal in terms of teaching methodologies, which must be adapted to the new philosophy governed by the cited parameters above. In this particular scenario the concept of the so-called 'innovation educational or teaching' takes on a key role when it comes to understanding these transformations and changes. Now, what is meant by 'innovation educational or teaching'? Cuenca, Solís, Guerrero, Rayón, Martinéz, Téllez and Hernández [4] stated that the nature of innovation is undoubtedly a fundamental aspect of the process and has been used to characterize multiple frames. A change improvement over a predetermined objective is the common element. In this context, as there is a great diversity of experiences that can hold the title of educational innovation, change may refer to i). an idea; ii). a material,; iii). a practice; iv). a content; v). a methodology; vi). a cultural pattern; vii). a relationship between persons or entities that are involved in the educational process; viii). how to apply a rule, an administrative procedure, an organizational device or belief or value [4]. In any case, it should always be taken into account that the innovation experience will be linked to a specific context, so that there will be ideas, themes, projects that will be innovative in some contexts but in others not.

It is also interesting to highlight the perspective provided by authors such as Havelock and Huberman [5] who put the incision in the systemic variable of innovation, i.e., understand innovation as a process for finding solutions to a problem that lies within a structure of systems, specifically three: the social system, the education system and the innovative educational project, which in turn encompass other subsystems. The greater degree of reciprocity is achieved between these three systems, the greater the degree of innovation [5].

\subsection{Projects of Teaching Innovation}

Within the current context of higher education is a reality of the loss of protagonism of the teacher, a figure that until relatively recently had full responsibility for student learning, and has gradually adopted a new role of teacher, tutor, who "teaches to learn". This in turn has the consequence that the student has abandoned its passive role, which is only limited to study notes taken fruit of the teacher's explanations in class and in taking an active role has led him to take charge of his own teachinglearning process.

Moreover, the professional context is more present than ever in developing the various curricula, in the same way as is the information and communications technology. The new educational model of higher education is therefore based on active didactic methodologies, and since the European universities have not turned their backs on this new educational situation. In this context the introduction of the use of new innovative strategies as a resource in teaching and learning has become a priority at the European University, which has been promoting various calls for what has been termed as 'Projects of Teaching Innovation' (PTI) '.

\section{2 'WHEN SCIENCE BECOMES INTERACTIVE': AN INTERNATIONAL PROJECT OF TEACHING INNOVATION}

The main pillars of the Project of Teaching Innovation "When science becomes interactive. A collaborative project in a teaching-learning network between the University of Salamanca, the University of the Basque Country and the Autonomous University of Lisbon", which was developed during the academic year 2015-16, were developed under the new pedagogical philosophy. The main objective of this project was the design and creation of "digital didactic materials in interactive format", which have been prepared jointly by students and professors of the University of Salamanca (USAL), the University of the Basque Country (UPV) and the Autonomous University of Lisbon (UAL) under the narrative hypermedia journalistic formats.

In this project, a total of 30 students participated (11 from the UPV / EHU, 10 from the USAL and 9 from the UAL) and 4 teachers (2 from the UPV / EHU, 1 from the USAL and 1 from the UAL) .

The innovation in teaching methodology used to articulate this project lies in the union of synergies between the areas of knowledge involved (science and literature), i.e. under the approach of a common practice students have worked on the different theoretical contents and the practical ones of the respective subjects with the objective of carrying out a joint work related to the contents of the 
subjects of 'General and Inorganic Chemistry' (University of the Basque Country) and the subjects of the Degree in Audio-visual Communication 'Genres Audio-visuals' (University of Salamanca) and the subject 'Online Journalism Workshop, taught at the Degree in Communication (Autonomous University of Lisbon). Therefore, this project is based on a methodology based on 'project-based learning'. Kilpatrick introduced the method in 1918. This professor at Columbia University argues that learning is best produced when it is a consequence of meaningful experiences, as this allows the student to be a partner in planning, production and understanding of an experience $[7 ; 8]$. Taking these methodological premises into account, we began to organize the work in different phases.

\subsection{Phase 1: Content Creation}

It is necessary to specify that the motive idea derived from the need to bring the students of the Degree in Pharmacy to a traditionally rough subject when it comes to imparting and studying: 'Descriptive Chemistry'. For this reason the first step was to conduct a rethinking of the contents of this subject by the teachers that taught (UPV / EHU), which chose to give guidance for the contents of the subject of study relating it to 'Chemistry Bioinorganic', providing them with a link of union, taking advantage of the great importance of this matter for the future pharmacists. Once these contents materialized, we proceeded to work on them with the students. Given that the ultimate goal was to give such content digital platform was necessary as a joint effort with both students at the UPV (content) and the USAL and UAL (technology tools).

\subsection{Phase 2: Development and design of tools for interaction-participation among project team members}

Regarding the development and design tools for interaction-participation of the project, it is interesting to note at this point one of the main innovations presented by this PTI was the use of social networks, specifically Facebook, as an educational tool. That is, a closed Group was created in the social network that allowed the communication and organisation of the teamwork. It should not be forgotten that in this project students and professors from three cities of two countries participated and, for this reason, Facebook was chosen as a tool mainly used among students, which enables interaction at any time and place. From a technological point of view, this option facilitated the exchange of multimedia material generated for the PTI among all participants. In short, it can be said that this Facebook group, served as the main platform where the interaction-participation was carried out when students and teachers were working. In addition to this tool, among the teachers e-mail was also used and students created a group in WhatsApp to communicate.

\subsection{Phase 3: Digitizing content}

Finally, this project involved a series of tasks related to the digitization of the various contents in which it was decided to work. Where students at the UPV / EHU were taking pictures, videos and audios related to the subject of Chemistry Bioinorganic'. They then exchanged with students of the University of Salamanca and Universidade Autónoma de Lisboa so that they could prepare to change the contents into a Web page, which also involved the use of other interactive tools like Joomag and ThingLink.

\section{RESULTS}

The achievement of this project has allowed: i). to materialize the interdisciplinary and the transversally between areas that at first could seem that they are totally disconnected, but that have found their union under didactic ends and within the search of synergies to carry out innovative teaching practices within the different subjects in such a way that with them the students have been actively and dynamically involved in the processes of teaching to learning; ii). use of the different digital communicative tools in order to give visibility to the practical assignments, materializing the socalled 'virtualization of teaching contents' in this case through the elaboration of a web page as a Scientific Magazine where the contents on "Descriptive Chemistry" have been published, being accessible online.

The new curricula within the framework of the EMHE offer a greater relevance to the autonomous work of the student and, therefore, to the practical part of the contents taught within a subject. However, contents of a course still remain accessible mainly for the students and teacher and rarely are shared with other students and teachers from the same or different area, a fact that is considered 
as a loss of potential for mutual enrichment between the different members of the university community. In order to achieve this goal, it has been necessary to incorporate new teaching methodologies that contemplate the collaborative work of a network between teachers and students in an environment of Teaching-virtual learning, indispensable since the members of the PTI were from different Universities (national and international levels). From a methodological perspective, one of the main innovations was the use of social networks, which means the use of Facebook for educational purposes. All organisational tasks and exchange of teaching materials between the different working groups created have been transmitted through such a tool both privately (closed Facebook group) and public (Web page). Another innovation was the introduction of students in the learning of the new professional environments that are currently required in the professional context, increasingly 'global' and 'digital'.

\section{CONCLUSIONS}

Adequate scientific knowledge is an indispensable quality for a good scientist. Its value as a communicator, however, is an addition that can be questioned. Scientists often suffer from poor communication with other sectors of society. Not only that, but also underlies the idea that greater complexity in explanations carries a greater depth of reasoning. On the other hand, more and more people are promoting an approach of scientists to society in a wrong way. Therefore, the idea of sharing Science among society was one of the achievements of this project.

Within this spirit, coupled with the idea of cooperation between universities, it emerged this collaborative project jointly participating teachers from the Area of Audio-visual Communication of the University of Salamanca, the Department of Communication Sciences at the Autonomous University of Lisbon and the Department of Inorganic Chemistry of the Faculty of Pharmacy at the UPV and which underlies the idea of contributing to the extent possible to share knowledge and experience from two dimensions: 1). the academic part between teachers and mainly between students of different degrees in areas of Science and Communication Sciences that has been reflected in the virtualisation of teaching contents (practical work of students); 2). the virtualisation of the contents in a digital platform supposes the internationalization of the educational contents generated in the framework of regulated teaching.

The materialised issues exposed a true educational innovation and transfer of knowledge that by way of summary are specified in the following: 1). coordination (at the level of teachers and students) and interdisciplinary (in different areas of knowledge); 2). the promotion of teamwork not only among students, but also among teachers, essential within the new curricula contemplated by the Bologna Plan; 3). the exchange of teaching methodologies and practices among the agents involved in this PTI; 4). the work in network, through the new processes of teaching-learning through the social network of Facebook; 5). the creation and promotion among students of processes of dynamic and participatory learning, which have allowed the students in a fun and enjoyable way of doing Science, without this entailing a loss of scientific rigor when working the different contents of subjects; 6 ). a project-based learner's learning, taking into account that the students of the mentioned subjects must carry out hypermedia contents that will give content to a web page in digital format; 7 ). the promotion of interculturality and the internationalization of knowledge through the publication of educational content in online support; 8). the modernization of teaching and learning techniques.

\section{REFERENCES}

[1] G. López, El ecosistema digital: modelos de comunicación, nuevos medios y público en Internet, Valencia: Servei de Publicacions de la Universitat de València, 2005.

[2] M. V. Haro, "Novedades docentes en el EEES. Madrid, Visión libros, 2012B. Martin, "Activism, social and political", Encyclopedia of Activism and Social Justice, pp. 19-27, 2007.

[3] D. Caldevilla, "EI EEES en España: una reforma más allá de la Universidad", Sapiens 2010, vol. $11, \mathrm{n}^{\circ} 02$, pp. 17-22.

[4] P. O. Cuenca, M. E. R. Solís, J. L. T. Guerrero, A. E. L. Rayón, C. Y. S. Martínez, L. S. Téllez, and B. R. Hernández, "Modelo de innovación educativa. Un marco para la formación y el desarrollo de una cultura de la innovación", RIED. Revista iberoamericana de educación a distancia, vol. 10, n 1, 2007. 
[5] R. G. Havelock and A. M. Huberman, "Solving Educational Problems: The Theory and Reality of Innovation in Developing Countries. IBE Studies and Surveys in Comparative Education", 1977.

[6] R. Yin, Case Study Research: Design and Methods, Thousand Oaks, California, Sage Publications, 1994.

[7] L. Luzuriaga, Antología pedagógica, Buenos Aires: Biblioteca Pedagógica Editorial Losada, 1968.

[8] J. W. Kilpatrick, "Una teoría de la nueva educación acomodada a nuestro tiempo" in "Ideas Pedagógicas del siglo XX" (L. M. Luziriaga, Org.), Buenos Aires: Biblioteca Pedagógica Editorial Losada, 1968. 